\title{
CONVENTIONAL AND VOLATILE SALTS AS PRECIPITATING AGENTS FOR RECOMBINANT ANTIVIRAL PROTEIN
}

\author{
SAIS CONVENCIONAIS E VOLÁTEIS COMO AGENTES DE PRECIPITAÇÃO \\ PARA PROTEÍNA RECOMBINANTE COM AÇÃO ANTIVIRAL
}

\author{
Kamilla Alves CARVALHO ${ }^{1}$; Dalton Giovanni Nogueira DA SILVA²; \\ Ronaldo Zucatelli MENDONÇA ${ }^{3}$; Erika Ohta WATANABE; \\ Fabiana Regina Xavier BATISTA ${ }^{4}$
}

1. Mestranda do Programa de Pós-Graduação em Engenharia Química, Universidade Federal de Uberlândia, MG, Brasil. alveskamilla4@gmail.com; 2. Doutorando do Programa de Pós Graduação Interunidades em Biotecnologia, Universidade de São Paulo - USP, Instituto Butantan/IPT, SP, Brasil; 3. Pesquisador Laboratório de Parasitologia, Instituto Butantan, SP, Brasil; 4. Professora, Doutora, Faculdade de Engenharia Química, Universidade Federal de Uberlândia - UFU, Uberlândia, MG, Brasil.

\begin{abstract}
Recombinant proteins expressed in cell culture have been shown to be relevant in the biopharmaceutical production focusing human health. The current work investigated the precipitation process of recAVLOEc protein, synthesized by E. coli BL21 (DE3) pLysS cells. The system is used for the AVLO expression that shown antiviral activity and it was found in the hemolymph of Lonomia obliqua caterpillar. The precipitation was conducted by the use of conventional salts (ammonium sulfate and sodium sulfate) and the volatile ammonium carbamate salt. Initially, the precipitated protein obtained from bacterial lysate was added to L929 cells to evaluate the cytotoxic effect; and besides Vero cells were infected with measles virus to verify the antiviral action of the precipitated recombinant protein. Toxic effect on the culture of L929 cells was observed for the precipitate obtained by the use of ammonium sulfate and sodium sulfate. In addition, tests in L929 cell cultures infected with EMC virus showed that samples of precipitated protein by salts did not show antiviral action. In Vero cell cultures, the precipitated protein by sodium sulfate showed antiviral action for measles virus.
\end{abstract}

KEYWORDS: Measles. recAVLOEc. Salting out. Volatile salt.

\section{INTRODUCTION}

In the last decade, the recombinant protein production by prokaryotic expression systems was widely used. However, once produced, the protein concentration and purification might be performed. In general, these procedures are expensive and often provide negatively influence to the protein's activity. Besides that, the protein recovery and purification require around $85 \%$ of the pharmaceutical production cost (TWYMAN et al., 2003). Therefore, the number of steps and the efficiency of each one have shown essential to the success of downstream procedure.

The protein precipitation is a common technique for concentrating and purifying proteins from solution (COEN; PRAUSNITZ; BLANCH., 1996). Different precipitation methods, such as addition of salts, polymers, organic solvents, metal-ion affinity ligand and isoelectric precipitation have been reported (VOET; VOET, 2010). Precipitation induced by salt known as salting-out precipitation is the most widely used for crude purification proteins from solution. In the salting-out precipitation, an aqueous protein solution is forced to undergo a phase separation by the addition of amounts of salts, such as ammonium sulfate or sodium sulfate. However, the salt from the protein precipitate and salt-rich aqueous phase must be removed in postprecipitation treatment steps. In face of that, the use of volatile electrolytes may be considered as a potential alternative to the precipitation by conventional salts. These volatile electrolytes can be removed from the precipitate and solution phases by temperature increase or pressure decrease; and then properly disposed or recycle in the process (WATANABE et al., 2006).

The recombinant protein was originally synthesized by $E$. coli BL21 (DE3) pLysS prokaryotic expression system and, as reported by Silva (2014), the protein was full capable to reduce in 157-fold the measles viral titer in infected Vero cell cultures. The aim of the current work was to evaluate the salting-out precipitation of recAVLOEc protein, potentially used as an antiviral agent, by conventional (ammonium and sodium sulfate) and volatile (ammonium carbamate) salts as precipitating agents.

\section{MATERIAL AND METHODS}

Samples of a bacterial expression clone (E. coli BL21 DE3 pLysS), developed by Silva (2014) and producing the intracellular recAVLOEc protein, with potential antiviral action was stored at $-30{ }^{\circ} \mathrm{C}$. These samples were 
Conventional and volatile...

thawed at room temperature and resuspended in PBS buffer solution ( $\mathrm{pH}=7)$. At this time, an anti-proteolytic solution (Protease Inhibitor Cocktail, Sigma- Aldrich, USA) was added at a ratio of $1 \mathrm{uL} / \mathrm{mL}$ and after that the mechanical procedure for cell lyses was performed. The cells were disrupted by ultrasound (Ultrassonic Processor, Sonics) during 20' (1 on / 2 off) using an ice bath. Then, the crude extract was centrifuged $(13,824 \mathrm{xg})$ for $40^{\prime}$ at $22{ }^{\circ} \mathrm{C}$ to remove debris.

Complementary, the crude extract obtained by ultrasound disruption was applied in a $15 \%$ SDS Page Gel Electrophoresis. After that, the gel was submitted to a transfer process of the sample to nitrocellulose membrane voltage of 200 Volts, under refrigeration. Membranes were blocked during 2 hours using PBS solution supplemented with skimmed milk (10\%m/v). Three washes for five minutes using PBS with $0.05 \%$ Tween were performed and thereon the membrane was incubated by 60' at room temperature with the anti-His antibody GE Healthcare. Furthermore, samples were revealed after the incubation with anti IgG antibody conjugated with HRP (Horseradish Peroxidase) GE Healthcare. It is important to note two different conditions were evaluated, Clone AVLOEc-N-C-His/ pET28a induced and not induced. The salt solutions (ammonium and sodium sulfate from Vetec and ammonium carbamate from Fluka, Sigma) were previously prepared from the addition of the salt to pure water, under stirring, until the salt saturation concentration was obtained. These assays were performed in $1.5 \mathrm{~mL}$ Eppendorf tubes. The salt solution was added to the total protein from the cell lysate to produce $1.0 \mathrm{~mL}$ systems of desired compositions. The tubes were sealed, kindly stirred at room temperature to homogenization and they were maintained by $24 \mathrm{~h}$ at $5^{\circ} \mathrm{C}$ in a thermostatic bath. After that, the supernatant and precipitate phases were separated by centrifugation at $13,824 \mathrm{x} \mathrm{g}$ for 30 '. The total protein of the supernatant and precipitate phases was determined by Bradford protein assays (BRADFORD, 1976). In addition, the ammonium carbamate and water were removed from precipitate phase by freeze drying at $377 \mu \mathrm{Hg}$ for $24 \mathrm{~h}$ using a freeze-dryer (L101, LIOBRAS). All experiments were performed in triplicate.

Vero cells, derived from kidney African green monkey (Cercopithecus aethiops), were used in the current work. In addition, L929 cell line, originating from adipose tissue of mice, was used for the cytotoxicity assay. Both cell lines were cultured in T-25 flasks using L-15 basal
CARVALHO, K. A. et al

medium with $10 \% \mathrm{SFB}$ and at $37^{\circ} \mathrm{C}$ without carbon dioxide environment. The EMC picornavirus and the measles virus were evaluated for the potential antiviral action of the precipitated protein.

Protein samples from cell lysate were added into L929 cell cultures. Initial protein concentrations of $190.5 \mathrm{mg} / \mathrm{L}, 493.88 \mathrm{mg} / \mathrm{L}$ and $156.17 \mathrm{mg} / \mathrm{L}$ obtained by ammonium sulfate, ammonium carbamate and sodium sulfate precipitating agent, respectively, were used. The cytotoxicity analysis was performed after $72 \mathrm{~h}$ of protein samples administration. Cell morphology was monitored in the inverted microscopy and 0.4 $\%$ crystal violet was used to enable a qualitative analysis of toxic effect of protein in relation to the cell culture (control).

The antiviral activity of the precipitated protein by salting out was performed using L929 cell cultures inoculated with the EMC picornavirus. The initial viral titer was $10^{3}$ TCID $50 / \mathrm{mL}$ and it was serially diluted in the ratio 2. After that, it was added to 96-well plate one hour after the contact of the cells with the precipitates. Thus, after $72 \mathrm{~h}$ and washing procedure, the dead cells due to viral infection have been removed. A similar procedure was performed for measles virus (Edmonton strain) but using Vero cells. Furthermore, the measles viral titer used was $10^{2} \mathrm{TCID} 50 / \mathrm{mL}$ and it was evaluated for cytopathic effect after $96 \mathrm{~h}$.

\section{RESULTS AND DISCUSSION}

Recently, insect hemolymph researchers demonstrated the presence of active principles for the development of new pharmacological drugs such as antiviral. Silva (2014), in their investigation demonstrated there is a potent antiviral in the Lonomia obliqua caterpillar's hemolymph. In this context, a protein with 24.6 $\mathrm{KDa}$ and 226 amino acids was cloned and expressed in a bacterial expression system. Following expression, the protein was detected on western blot using anti-His antibody and the bacteria were then sonicated. The crude supernatant was affinity purified by histidine tail using magnetic beads and the HisTrap FF $5 \mathrm{~mL}$ column. After that, this purified protein has reduced the viral titer (TCID50/mL) of measles (157-fold) and H1N1 influenza virus (64-fold). Alternatively, the protein purification was performed in the current work by a single stage using salts as a precipitating agent. Thereon, the target-protein (recAVLOEc) into the cell lysate from bacterial expression system (E. coli BL21 
Conventional and volatile...

(DE3) pLysS) was evaluated in a cytotoxicity trial and tested to the protection of L929 cells infected with EMC picornavirus and Vero cells infected with measles virus.

In order to verify the target-protein in the cell lysate from bacterial expression system a western blot was performed and the result is presented in Figure 1. As observed, since that the anti-His antibody was used; it was possible to
CARVALHO, K. A. et al

detect the recombinant protein (Lines 2 and 4 ) in the cell lysate. It suggested successful cloning/expression constructs (E. coli BL21 (DE3) pLysS). The solubility curve of the total protein from cell lysate, containing the targetprotein (recAVLOEc), in volatile salt solution and conventional salts (ammonium sulfate and sodium sulfate) solutions showed a decrease of protein concentration in the supernatant phase (Figure 2).

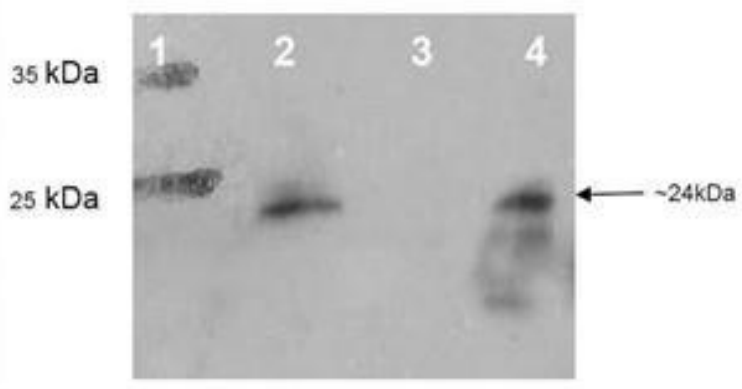

Figure 1. Western Blot of crude extract from bacterial lysate. 1 - Protein ladder; 2 and 4 - Clone AVLOEc$\mathrm{N}-\mathrm{C}-\mathrm{His} / \mathrm{pET} 28 \mathrm{a}$ induced crude extract; 3 - Clone AVLOEc-N-C-His /pET28a not induced crude extract.

The total protein solubility in ammonium carbamate solution was higher than in solutions of ammonium and sodium sulfates for $90 \%$ of salt saturation. It is important to note that ammonium carbamate has been considered an alternative to conventional salts for inducing phase separation in aqueous two-phase systems, and these systems have been used for protein separation. Protein concentration used in the precipitation assays was prepared so as to ensure the total protein solubilization in the medium. The solutions containing only protein, buffer and without salt remained unchanged. As discussed by Mariam et al. (2015), the phenomenon of protein precipitation is associated with the ionic interactions between salt, water and protein. Prior to the salt addition, the dissolved proteins form hydrogen bonding with water molecules

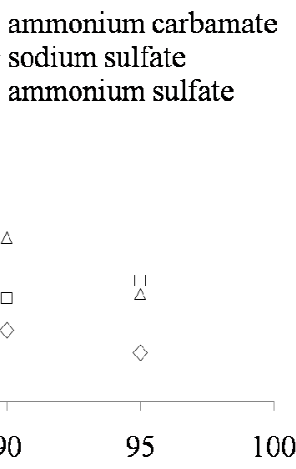

00

Figure 2. Solubility of total protein from cell lysate in conventional salts (ammonium and sodium sulphate)

and volatile salt (ammonium carbamate) supernatant. through the polar and ionic groups present on the proteins' surfaces. Upon the addition of small, highly charged ions such as ammonium or sodium sulfate to the solution, a competition between the salt ions and the proteins for interacting with water molecules occurred. If the concentration of salt ions is sufficiently high, the hydrogen bonding between protein and water can be eventually disrupted and the solubility of proteins in aqueous solution will decrease.

Accordingly, the protein-protein interactions become strong and this leads to the formation of protein precipitation. In addition, the volatile salt was fully removed by lyophilization pressure reduction process, according to the mass balance of protein in the supernatant and precipitated phase, in agreement with Watanabe et al., (2006). 
It was performed an analysis for cytotoxic activity of total protein from bacterial expression system using L929 cells (Figure 3). At low dilutions $(8 x, 32 x$ and $2 x)$, the total precipitated protein respectively with ammonium carbamate, ammonium sulfate and sodium sulfate showed considerable cytotoxic in vitro to the crude extract form. On the other hand, there is slight cytotoxic activity once $16 x$, $64 \mathrm{x}$ and $4 \mathrm{x}$ of protein sample dilutions. However, the use of diluted samples can cripple the testing, since it reduces not only the amount of salt in the medium as well as the protein of interest. Antiviral action of protein samples from bacterial lysate precipitated using ammonium sulfate, sodium sulfate and ammonium carbamate was accomplished by 96-plate containing cell cultures inoculated with EMC virus (data not shown). The action of EMC virus was not reduced in the presence of precipitated protein, since any of the samples reduced the cytopathic effect of EMC virus. After viral dilution factor of $8 \mathrm{x}$ the EMC virus did not provide cytopathic effect on the L-929 cells.

According to Silva (2014), recAVLOEc provide intracellular action and it could proceed on the viral replication mechanism. However, it might be consider that the precipitated protein may have suffered denaturation by saline action during the precipitation procedure, even in the presence of an antiproteolytic agent.

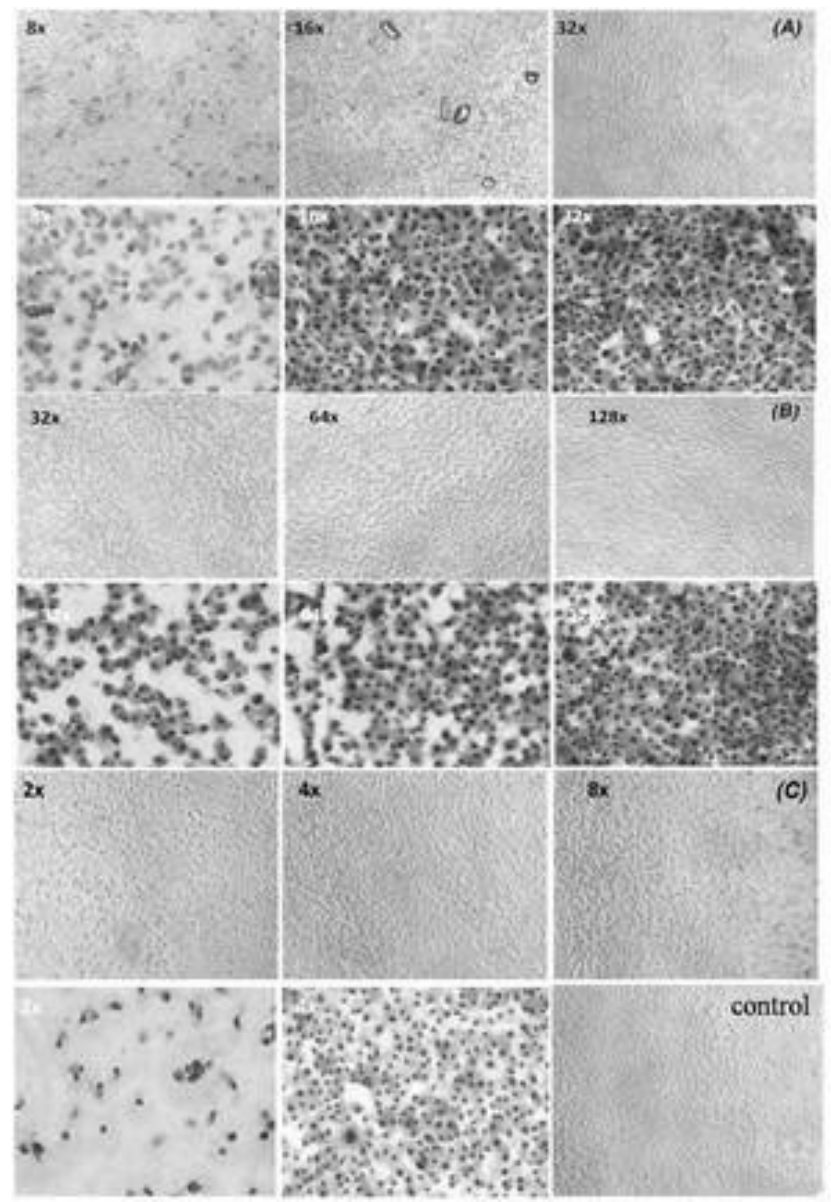

Figure 3. In vitro evaluation of cytotoxicity of the total protein precipitated by different salts. L929 cells were used. (A) ammonium carbamate [dilution factor of total protein 8x, 16x and 32x]; (B) ammonium sulfate [dilution factor of total protein 32x, 64x and 128x]; (C) sodium sulfate [dilution factor of total protein $2 \mathrm{x}, 4 \mathrm{x}$ and $8 \mathrm{x}$ ]. Violet crystal $(0.4 \% \mathrm{w} / \mathrm{v})$ were used to better view the effect of protein on the cell morphology, being the control established by viable cells (L929) cultivated in the basal L-15 medium supplemented with $10 \%$ FBS. 
In this sense, their biological action for the tested virus may have been affected. Finally, it might be also consider that the protein did not present antiviral activity for EMC virus. Following, Vero cell cultures were also inoculated with different viral dilutions in the presence of protein samples precipitated by the same salts. There was antiviral action of the precipitated protein obtained by sodium sulfate (factor dilution of $4 \mathrm{x}$ ). This can be seen once that after the precipitated protein factor dilution of $8 x$ for ammonium sulfate and ammonium carbamate there is not potential antiviral effect on the infected culture, since in these conditions the cell morphology was maintained similar to the cell control (data not shown). As at factor dilution of $4 \mathrm{x}$ for sodium sulfate precipitation the cell morphology it was similar to the cell control suggesting in this conditions that the precipitated protein resulted in antiviral activity for measles virus.
We attempted to concentrate sample proteins from the cell lysate by different conventional salts (ammonium sulfate and sodium sulfate) and volatile ammonium carbamate. Current study demonstrated that the precipitated total protein from bacterial lysate, containing the recAVLOEc, by sodium sulfate, has active principles involved in the antiviral activity for measles virus. Efforts are underway to carry out a complex steps to purification of the total protein and perform biochemical characterization of this fraction. Further experiments with the isolated protein fraction would be observed and the therapeutic potential of recAVLOEc would be verified in treatment of ailments.

\section{ACKNOWLEDGMENTS}

The authors acknowledge the financial support of FAPEMIG (grant APQ-00390-13).

RESUMO: Proteínas recombinantes expressas em culturas celulares têm se mostrado importantes na produção de fármacos de interesse para a saúde humana. Este estudo investigou a precipitação da proteína recAVLOEc, sintetizada por células de E. coli BL21 (DE3) pLysS, utilizadas como sistema de expressão da AVLO, proteína com atividade antiviral, originalmente encontrada na hemolinfa da lagarta Lonomia obliqua. A precipitação foi conduzida por meio do uso de sais convencionais (sulfato de amônio e de sódio) e do sal volátil carbamato de amônio. Inicialmente o precipitado proteico obtido do lisado bacteriano foi administrado em culturas de células L929 para avaliar o efeito citotóxico e posteriormente em células Vero infectadas com o vírus do sarampo, para a verificação da ação antiviral. Um efeito tóxico em culturas de L929 foi observado para os precipitados obtidos pelo uso de sulfato de amônio e de sódio. Testes em culturas de L929 infectadas com o vírus EMC foram também efetuados e as amostras de proteínas precipitadas com os sais convencionais e o sal volátil não resultaram em ação antiviral. Em culturas de células Vero, o uso do sulfato de sódio como agente de precipitação das proteínas contidas no lisado bacteriano resultou em ação antiviral para o sarampo.

PALAVRAS-CHAVE: Sarampo. recAVLOEc. Precipitação salina. Sal volátil.

\section{REFERENCES}

BRADFORD, M. A Rapid and Sensitive Method for the Quantitation of Microgram Quantities of Protein Utilizing the Principle of Protein-Dye Binding. Analytical Biochemistry, Georgia. v. 72, p. 248-254,1976. Disponível em: <http://www.upch.edu.pe/facien/fc/dbmbqf/zimic/cursos/prbq/material\%20de\%20clases/BradfordAnalBioc72 -248.pdf>. Acesso em: 06 mar. 2017.

COEN, C. J; PRAUSNITZ, J. M; BLANCH, H. W . Protein salting-out: Phase equilibria in two proteins systems. Biotechnology and Bioengineering, California. v. 53, p. 567-574, 1997. Disponível em: < https://dx.doi.org/10.1002/(SICI)10970290(19970320)53:6\%3C567::AID-BIT4\%3E3.0.CO;2-K> . Acesso em: 07 mar. 2017.

MARIAM, S. H. S; OOI, C. W; TAN, W. S; JANNA,O. A; ARBAKARIJA, A.; TEY, B. T. Purification of rabbit polyclonal immunoglobulin $\mathrm{G}$ with ammonium sulphate precipitation and mixed-modechromatography. Separation and Purification Technology, v. 144, p. 133- 138, 2015. Disponível em $:<$ http://dx.doi.org/10.1016/j.seppur.2015.02.012>. Acesso em: 07 mar. 2017. 
SILVA, D. G. Clonagem e expressão de proteína antiviral presente na hemolinfa de Lonomia obliqua por tecnologia de DNA recombinante em Escherichia coli.2014.117 f. (Tese de Doutorado em Biotecnologia) - Instituto de Ciências Biomédicas, Universidade de São Paulo, São Paulo, 2014.

TWYMAN, R. M.; STOGER, E.; SCHILLBERG, S.; CHRISTOU, P.; FISCHER, R. Molecular farming in plants: host systems and expression technology. Trends in Biotechnology, v. 21,n. 12, p. 570-578, 2003. Disponível em:<http://dx.doi.org/10.1016/j.tibtech.2003.10.002>. Acesso em: 07 mar. 2017.

VOET, D.; VOET, J. G. Bioquímica. 4. ed. São Paulo: Artmed, 2013,1504 p.

WATANABE, E. O., PESSÔA FILHO, P. A., MIRANDA, E. A., MOHAMED, R. S. Evaluation of the use of volatile electrolyte system produced by ammonia and carbon dioxide in water for the salting-out of proteins: Precipitation of porcine trypsin. Biochemical Engineering Journal, v. 30, n. 2, p. 124-129, 2006.Disponivel em :<http://dx.doi.org/10.1016/j.bej.2006.02.013>. Acesso em: 06 mar. 2017. 